\title{
IMPACT OF INTERNAL MARKETING ON CUSTOMER ORIENTATION OF EMPLOYEES: MEDIATING ROLE OF EMPLOYEE BRAND IDENTIFICATION
}

\author{
Dr. Renjini D. \\ Associate Professor, DDU KAUSHAL KENDRA, \\ Cochin University of Science and Technology, Kerala, India
}

\begin{abstract}
Customer orientation of employees plays a critical role in service organizations as it has direct influence on service quality and customer experience. Customer orientation, an integral component of external market orientation, is therefore one of the most important employee-level outcomes sought by organizations. Several organizations adopt internal marketing practices so as to elicit appropriate workbehaviours such as customer orientation. Though literature supports the positive impact of internal marketing on customer orientation, there is no adequate research attention on mediators and moderators on this relationship. The present paper is an attempt to conceptually analyse the potential mediating influence of employee brand identification on the relationship between internal marketing and customer orientation. Based on an extensive review of both theoretical and empirical works in the fields of marketing, service management and organizational behaviour, a conceptual model is offered to explain the relationship among the above-mentioned variables.
\end{abstract}

Key words: internal marketing, customer orientation, brand identification, organizational identification, internal marketing orientation, internal branding

Cite this Article: Renjini D, Impact of Internal Marketing on Customer Orientation of Employees: Mediating Role of Employee Brand Identification, International Journal of Management, 11(12), 2020, pp 2300-2306.

http://iaeme.com/Home/issue/IJM?Volume=11\&Issue=12

\section{INTRODUCTION}

In line with the shift from transaction-based marketing to relationship marketing, customer experience and customer engagement occupy central place in firms' strategies for building competitive advantage, especially in service sector. Customer-oriented employees are therefore vital assets without which service firms will find it impossible to deliver consistent 
and meaningful customer experience (Zablah et al., 2012). Firms that consistently provide unique customer experience stay ahead of competition and stay relevant to the markets. Hence there is an understandable thrust on delivering superior customer value and ensuring superior customer experience, especially in service industry. It is a well-established fact that customer orientation is an absolute necessity for organisations to design and deliver superior customer value and experience. Thus, despite the scepticism about the strategic competitive source of a competitive advantage of customer orientation expressed in recent literature, customer orientation is still considered an important asset for organizations, especially in emerging economies context where the relative strength of market orientation to impact performance is more compared to developed world where market orientation is a necessary condition for success rather than a foundation of one's competitive strength. Several empirical studies in service literature and marketing underscores the importance of custom orientation by demonstrating its impact on various positive outcomes such as job satisfaction(Pettijohn et al., 2002); organizational commitment (Stock and Hoyer, 2002); and organizational citizenship behaviour (Donavan, Brown et al,2004)

The fact that role of employees in ensuring external market orientation is vital is common knowledge as widely recognised in literature. Backing of employees is considered integral to building market-oriented culture in organizations (Harris, 2002). Alignment of attitudes and value systems of employees with the demands of market-oriented culture is an important organization resource for effective implementation of market orientation in organizations. This alignment of individual level attitudinal variables and market orientation values at organizational level assumes more significance in organizational and market contexts where traditionally organizational/individual values can be in conflict with market orientation values. Internal marketing originates from an organization's internal market orientation which is in fact application of market orientation to the organization-employee exchange within an organizational context. Gounaris (2006) defines internal market orientation (IMO) as "the manifestation of the company's effort to generate value for the employees so that employees genuinely contribute to the company's effort to generate value for the customer'. The definition clearly brings out the crux of the concept as treating employees as customers of the organizations where organizations ensure value for employees in return of desired employee behaviours at work. IMO creates value for employees just the way firms design and create customer value; by understanding and responding to their needs.

Despite the wide acceptance of internal marketing and its positive impact of organisational outcomes, research in the area has been limited in scope and application. Most studies in the filed centre around the activities and organizational process that make up internal marketing (Wittke-Kothe, 2001). Role of employee-relevant variables have been discussed extraordinarily little in literature despite the obvious role of employees in brandingsupporting behaviours' inside organizations. This paper tries to analyse the role employee brand identification, an important direct outcome that is ought to be sought through internal marketing by organizations, in generating customer orientation of employees. First, we present a detailed review of pertinent literature to come to proposed relationships among the variables. The resultant conceptual model helps to shed light on how customer orientation of employees can be enhanced by internal marketing practices of companies.

\section{LITERATURE REVIEW AND DEVELOPMENT OF PROPOSITIONS}

\subsection{Internal Marketing and Customer Orientation}

Customer orientation is a component of external market orientation of firms. It represents the organizational philosophy of customer centricity whereby organizations place customer at the centre of organizational activities to align the activities towards achieving customer 
satisfaction. Some view customer orientation as part of a continuum where sales and customer orientations occupy the two extreme points (Saxe and Weitz, 1982). Front-line employees are critical in ensuring desirable employee-customer interactions in service environment (Parasuraman et al., 1985). Customer perception of customer orientation by firms are largely shaped by customer's evaluation of their interactions with employees (Wieseke, Ullrich, et al 2007). At an individual employee level, especially in customer-facing roles, customer orientation means one's orientation towards understanding customer needsand eagerness to help customers meet their needs rather than thrusting company's products on customers. Sales orientation, on the other hand implies employee focus on short-term sales even by highpressure selling techniques (Saxe and Weitz, 1982). Employee customer orientation is conceptualised to be comprised of four dimensions namely, technical skills, social skills, motivation to meet customer needs, and the authority to take decisions in matters related to customer requirements (Hennig-Thurau and Thurau, 2004).

Service firms across various domains face intense competition forcing several firms to invest heavily in branding efforts to differentiate their service offers and build and sustain competitive advantage (Sharp, 1995; Samli \&Frohlich, 1992). Employees play key roles in these initiatives. Consistency in service delivery and quality of customer experience are central to ensuring customer loyalty and long-term profitability of service firms. Employee motivation and engagement can influence quality of service and customer experience. Thus, employees, especially those at customer-interfacing roles, are an important asset and a potential foundation for building sources for competitive differentiation in the market. Organizational efforts to ensure employee skills and motivation can therefore be considered part of larger branding strategy implementation (Punjaisri \&Wilson, 2007). Organizations have to first sell the brand to its internal audience before it sells it to external markets. Studies have reported positive impact on employee level outcome such as job satisfaction, commitment, and intention to stay (Preez and Bendixen, 2015)

IMO adoption can help organizations win employee support in implementing organizational behaviours that are consistent with market orientation (Lings, 2004). An organization which practices internal market orientation understand employee needs and aspirations closely so that it can formulate relevant and suitable policies, making employees feel valued and cared for. This in turn elicits appropriate work-related behaviours from employees. Internal marketing involves applying marketing techniques in the context of market component of internal market consisting of employees of an organization. Marketing practice can be applied to the human resource management activities of attracting, developing, motivating and retaining talents in an organization (Berry \& Parasuraman, 1991). Internal marketing is founded on the concept of treating employees as internal customers who must be acquired, managed and retained just as external customers of the organization (Berry, 1981). It is also linked to employees' education and training for encouraging market-oriented behaviours of customers and is ensured through marketing activities like external marketing (Snell \& White, 2009). Another angle to view internal marketing is through relationship marketing (George, 1990; and Ballantyne, 2000).

Internal marketing is believed to lead to better external marketing outcomes for organizations Ballantyne, 2000; and Gronroos, 2000). Effective internal marketing has been associated with customer orientation and overall performance (Chang and Chang, 2008; Narteh, 2012; and Ali, 2012). Internal marketing is educating and motivating employees of an organization so that employees exhibit customer-oriented behaviours (Snell and White, 2009). Internal marketing comprises of internal communication, employee rewards, training and education and employee empowerment. Internal communication is treated as a marketing function where organization communicates with the internal target audience consisting of its 
employees (Welch and Jackson, 2007). Reward systems, training and continuous education also make the components of internal marketing (Papasolomou \& Vrontis, 2006). Another important constituent of internal marketing is employee empowerment (Narteh, 2012). In line with Social Exchange Theory, employees reward organisations with appropriate behaviours in exchange of their need gratification through positive exchanges with the organizations. Internal marketing results in positive exchanges for employees by enhancing employee training, internal communication and other employee-targeted activities and thus, help elicit desired responses from employees.

Hence, we propose that,

Proposition 1: Internal marketing contributes to customer orientation of employees

\subsection{Internal Marketing and Employee Brand Identification}

Brand identification can be understood as an individual employee's sense of belongingness to the brand (Punjaisri and Wilson, 2011). Employees with high brand identification perceive the brand as their own and consider brand's success and failure as personal and intimate. Theoretical foundations are often traced to the social identity theory (Tajfel and Tumer, 1985). Brand Identification is considered important in service-contexts as service employees are crucial in service-delivery to customers. Employees, especially at the customer-facing level, employees represent the brand promise to the outside world and hence actualise the brand positioning. Brand identification is similar to organization identification in that there is "perceived oneness between the self and the organization" (Shenet al., 2014). Brand identification is mostly explained through social identity theory. Brand identity can be considered to a group identification among employees which occurs when employees incorporate the brand identity within their self-concept (Mael \& Ashforth, 1992; Tajfel\&Turner, 1985). Studies (Aurand, Gorchels, and Bishop, 2005; Burmann and Zeplin, 2005) show that when employees share brand meaning, they develop identification with the brand and show higher commitment towards bringing about the brand promise to the external stakeholders. Employees acts as a link between brand and customers, producing better brand loyalty among customers (Papasolomou \& Vrontis, 2006). Through internal marketing, organizations can develop their employees' knowledge of the brand promise. Internal marketing, by marketing the organization's overall philosophy and its promise to its employees can help enhance organizational identification among employees.

Proposition 2: Internal marketing leads to enhanced brand identification among employees

\subsection{Brand Identification and Customer orientation}

Brand identification comprises of both cognitive and affective components (Johnsonet al., 2012). Cognitive component results in one's perception on belongingness to an organization. Affective identification is more about one's favourable feelings about being part of an organization or belonging to a brand. Literature points at better predictive power for affective identification when it comes to behaviour. Punjaisri and Wilson (2011) reports that brand identification influences brand-supporting employee behaviour. Also, by psychological approach to individual customer orientation where customer orientation is seen as a workvalue, customer orientation can be enhanced by employee brand identification through positively influencing one's motivation to engage in behaviours aligned with customer orientation. Customer orientation of employees refers to employees' knowledge of customer needs and proactive actions on their part to satisfy those needs. Employees who identify well with the organization and the brand are more likely to expend energy and time to proactively seek to satisfy customer needs. Therefore, we propose that 
Proposition 3: Employee brand identification positively influences customer orientation of employees

\subsection{Mediational Role of Brand Identification}

Entire impact of internal marketing on customer orientation cannot be considered to be direct. It must be working through some intervening variables which prompt employees to display high customer orientation. Internal marketing can enhance customer orientation by equipping employees to be more responsive to customer requirement through training, internal communication and empowerment. We argue that a part of internal marketing impact is through the mediational influence of brand identification. Successful branding in the external market can thus be considered to start from internal branding where employees identify with the brand and feel committed to the brand. Thus, we propose that brand identification mediates the link between internal marketing and customer orientation.

Proposition 4: Internal marketing influences customer orientation of employees through the mediating influence of brand identification

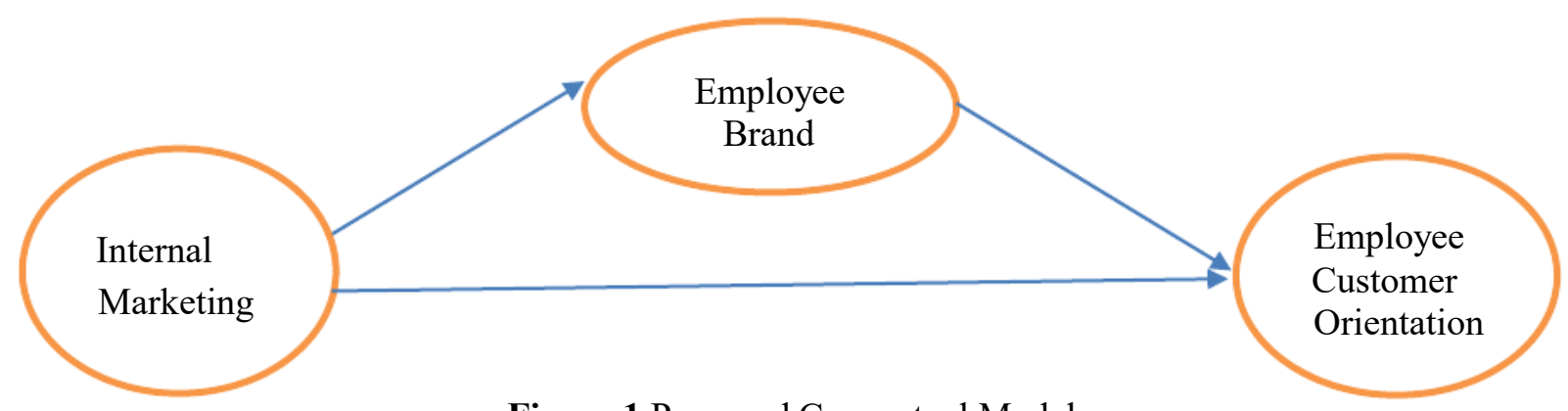

Figure 1 Proposed Conceptual Model

\section{CONCLUSION AND IMPLICATIONS}

The study makes some important contributions to theory and practice. First, by linking internal market orientation to market orientation through employee customer orientation, the paper emphasizes the role of employees in effective implementation of market orientation. Attitude and behavioural fit of employees is an important pre-condition for successful organization-wide acceptance and adoption of external market orientation. This has some policy implications for management, especially in human resource policies design. Training and development should orient toward inculcating customer orientation among employees at all levels. Training has added significance in employees who do not have customer-facing roles. In such job positions, impact of one's organizational activities on customer satisfaction is not easily evident and direct. The paper also underlines the role of IMO as a human resource management tool beyond sales and customer-service positions. Paper also responds to the call for integrating and examining the impact of marketing on other business function by looking at the interrelationship of marketing outcomes, employee management practices and employee-level attitudes. Despite the contributions to theory and practice, the study does have some limitations which must be mentioned here. The study is conceptual in nature and therefore, presents no empirical support for the proposed relationships among variables. An empirical analysis of the model could certainly be a promising area for future research. Future studies, especially empirical ones, can also investigate the probable impact of moderating variables such as employee's self-efficacy on the relationship between internal marketing and customer orientation of employees. 


\section{REFERENCES}

[1] Aurand, T.W., Gorchels, L., \& Bishop, T. R. (2005). Human resource management's role in internal branding: An opportunity for cross-functional brand message synergy. Journal of Product \& Brand Management, 14(3) 163-169.

[2] Burmann, C. \& Zeplin, S. (2005). Building brand commitment: A behavioural approach to internal brand management. The Journal of Brand Management, 12(4), 279-300.

[3] Ballantyne, D. (2000). Internal relationship marketing: a strategy for knowledge renewal. The international journal of bank marketing, 18(6), 274-286.

[4] Balmer,J. and Wilkinson,A.(1991)'Building societies: Change, strategy and corporate identity', Journal of General Management, Vol. 17, No. 2, pp. 20 - 33.

[5] Berry, L.L. (1981), “The employee as customer”, Journal of Retail Banking, Vol. 3 No. 1, pp. 33-40 Berry, L.L. and Parasuraman, A. (1991), Marketing Services: Competing through Quality, The Free Press, New York, NY.

[6] Bharadwaj, S. G., Varadarajan, R . P. and Fahy, J. (1993) "Sustainable competitive advantage of service industries: A conceptual model and research propositions", Journal of Marketing, Vo 1. 57, pp. $83-99$.

[7] Brown, T. J., Mowen, J. C., Donavan, D. T., \& Licata, J. W. (2002). The customer orientation of service workers: Personality trait effects on self-and supervisor performance ratings. Journal of marketing research, 39(1), 110-119.

[8] Chang, C.S. and Chang, H.C. (2008), "Perceptions of internal marketing and organizational commitment by nurses", Journal of Advanced Nursing, Vol. 65 No. 1, pp. 92-100.

[9] George, W. R. (1990). Internal marketing and organizational behavior: A partnership in developing customer-conscious employees at every level. Journal of Business research, 20(1), 63-70.

[10] George, W.R. (1990), "Internal marketing and organizational behaviour: a partnership in developing customer-conscious employees at every level", Journal of Business Research, Vol. 20 No. 1 , pp. 63-70.

[11] Gounaris, S.P. (2006), "Internal-market orientation and its measurement”, Journal of Business Research, Vol. 59 No. 4, pp. 432-448.

[12] Hennig-Thurau, T. (2004), Customer orientation of service Employees. Its impact on customer satisfaction, commitment, and retention. International Journal of Service Industry Management, 15(5), 460-478.

[13] Mael, F.A. and Ashforth, B.E. (1992), "Alumni and their alma mater: a partial field test of the reformulated model of organizational identification", Journal of Organizational Behaviour, Vol. 12 No. 2, pp. 102-123.

[14] Narteh, B. (2012), "Internal marketing and employee commitment: evidence from the Ghanaian banking industry", Journal of Financial Services Marketing, Vol. 17 No. 4, pp. 284300 .

[15] Papasolomou, I. and Vrontis,D. (2006) 'Using internal marketing to ignite the corporate brand: The case of the UK retail bank industry', Journal of Brand Management, Vo 1. 14, No. 1/2, pp. $177-195$.

[16] Parasuraman, A., Zeithaml, V.A. and Berry, L.L. (1985), A Conceptual Model of Service Quality and Its Implications for Future Research. Journal of Marketing, 49 (Fall), pp. 41-50.

[17] Pettijohn, C. E., Pettijohn, L. S., \& Taylor, A. J. (2002). The influence of salesperson skill, motivation, and training on the practice of customer-oriented selling. Psychology \& Marketing, 19(9), 743-757. 
[18] Punjaisri, K. and Wilson, A. (2011), "Internal branding process: key mechanisms, outcomes and moderating factors", European Journal of Marketing, Vol. 45 Nos 9/10, pp. 1521-1537.

[19] Punjaisri, K., \& Wilson, A. (2017). The role of internal branding in the delivery of employee brand promise. In Advances in corporate branding (pp. 91-108). Palgrave Macmillan, London.

[20] Samli, A. and Frohlich, C. (1992) "Service: The competitive edge in banking', Journal of Services Marketing”, Vol. 6, No. 1, pp. $15-22$.

[21] Sharp, B. (1995) 'Brand equity and market-based assets of professional service firms", Journal of Professional Services Marketing, Vol. 13, No. 1, pp. 3 - 13.

[22] Shen, Y., Jackson, T., Ding, C., Yuan, D., Zhao, L., Dou, Y. and Zhang, Q. (2014), "Linking perceived organizational support with employee work outcomes in a Chinese context: organizational identification as a mediator", European Management Journal, Vol. 32 No. 3, pp. 406-412.

[23] Snell, L., \& White, L. (2009). An exploratory study of the application of internal marketing in professional service organizations. Services Marketing Quarterly, 30(3), 195-211.

[24] Stock, R. M., \& Hoyer, W. D. (2002). Leadership style as driver of sales peoples' customer orientation. Journal of market-focused management, 5(4), 355-376

[25] Tajfel, H. and Tumer, I.C. (1985), "The social identity theory of intergroup behaviour", in Worchel, S. and Austin, W.G. (Eds), Psychology of Intergroup Relations, 2nd ed., NelsonHall, Chicago, IL, pp. 7-24.

[26] Wieseke, J., Ullrich, J., Christ, O., Van Dick, R (2007), Organizational identification as a determinant of customer orientation in service organizations. Marketing Letters, 18, pp. 265278.

[27] Wittke-Kothe, C. (2001) 'Interne Marken-f ü hrung — Verankerung der Markenidentit ä t imMitarbeiterverhalten', Deutscher Universit ä ts-verlag GmbH, Wiesbaden. 